\title{
Comparison of residue patterns between foliar application and drenching in export strawberry
}

\author{
Hyo-Sub Lee ${ }^{1}$ (D) $\cdot$ Su-Myeong Hong ${ }^{1} \cdot$ Hye-Young Kwon $^{1} \cdot$ Dan-bi Kim $^{1}$. \\ Byeong-Chul Moon ${ }^{1}$
}

\section{경엽 및 관주 처리에 따른 딸기 중 침투성 농약 잔류패턴 비교}

이효섭 ${ }^{1}$ · 홍수명 ${ }^{1}$ · 권혜영 ${ }^{1}$. 김단비 ${ }^{1}$ - 문병철 ${ }^{1}$

Received: 3 August 2017 / Accepted: 13 September 2017 / Published Online: 31 December 2017

(C) The Korean Society for Applied Biological Chemistry 2017

\begin{abstract}
Strawberries are one of the main commodities in Korea and have been exported over 30 million dollar. And the safety has recently become an important issue in the agro-trade, pesticide residue is most important matter of safe agricultural products. As strawberries can be cultivated using elevated production system, so it is possible to use the drenching. When spraying the pesticides, the use of drenching can be lower amount of residual than using foliar treatment. In this study, time sequential residual amount of pesticides were compared between drenching and foliar application in strawberries. Pesticides were treated with the standard and double dosage and samples were collected at $0,3,6$, 9, 13, 16 and 21 day and analyzed by LC and LC-MS/MS after liquid-liquid extraction and QuEChERS. Two pesticides were detected less than $1 \mathrm{mg} / \mathrm{kg}$ in all samples for drenching treatment. Carbendazim residues in drenching treatment were 5 to 25 times lower than foliar application. And azoxystrobin was not detected in strawberries of drenching treatment.
\end{abstract}

Keywords Azoxystrobin - Carbendazim · Drenching · Foliar application · Strawberries

\section{Hyo-Sub Lee $(\triangle)$}

E-mail:1hs8255@korea.kr

${ }^{1}$ Chemical Safety Division, Agro-Food Safety and Crop Protection Department, NAS, RDA, Wanju 55365, Republic of Korea

This is an Open Access article distributed under the terms of the Creative Commons Attribution Non-Commercial License (http://creativecommons. org/licenses/by-nc/3.0/) which permits unrestricted non-commercial use, distribution, and reproduction in any medium, provided the original work is properly cited.

\section{서 론}

21세기에 들어 전세계적으로 자유무역협정(Free Trade Agreement, FTA)이 체결됨에 따라 무역이 활발하게 이루어지고 있으며, 농 산물 또한 많은 양이 거래되고 있다. 더불어 소비자의 안전성 에 대한 관심 증대로 농식품 안전성은 농산물 무역에서 중요한 요인으로 작용하게 되었다. 농산물 무역에서 수출부적합의 원인 으로 잔류농약, 중금속, 곰팡이 독소 및 미생물 등이 있는데, 그 중에서 잔류농약은 가장 큰 수출 부적합 원인으로 작용하고 있 다(NAQS 2017). 수출 농산물 중 딸기는 농약으로 인한 부적합 률이 $26.7 \%$ 로 수출 농산물의 부적합 발생 건수 중 가장 높은 비율을 차지하고 있다(RDA 2017). 딸기 중 잔류농약의 철저한 관리는 딸기를 수출하는데 있어 중요한 요인으로 작용하고 있다.

딸기는 장미과에 속하는 다년초 작물로서 무기질, 비타민 $\mathrm{C}$ 가 풍부하고 항산화물질이 다량 함유되어 심혈관질환의 예방에 효과적인 것으로 알려져 있는 과채류로서(Azodanlou 등, 2003; Ayala-Zavala 등, 2004; Cho 등, 2004) 맛과 향이 좋아서 전 세계적으로 인기 있는 농산물로 자리매김 하고 있다(Park 등, 2011). 우리나라는 딸기 주요 수출국으로 2016년 약 3,000만 달 러 이상의 수출액을 기록하여 신선채소류 중 $11 \%$ 정도를 차지 하고 있다(MAFRA 2017).

하지만 딸기의 재배방식은 시설재배가 대부분으로 온실의 온 난 다습한 환경이 탄저병, 잿빛곰팡이병, 시들음병 등 여러 병 과 해충의 피해가 많이 발생하여(Nam 등, 2012) 농약을 사용 할 수 밖에 없는 실정이다. 그동안 시설토경재배지에서는 병해 충 방제시 엽면 처리방법으로 농약을 살포하였다. 그러나 최근 에 딸기의 재배방식이 고설재배로 전환되면서 점적관수를 이용 한 관주 처리 살포방법이 관심을 받고 있다.

고설재배는 토양이 아닌 베드에 점적관을 설치하여 양액 및 수분을 공급하는 농법으로(Kim 등, 2009) 수경재배 또는 양액 
재배라고 불리기도 한다. 현재 우리나라의 딸기재배 방식은 토 경재배에서 고설재배로 매우 빠르게 전환되고 추세로('08) 84.1 ha에서('14) 663.7로 6년 동안 연평균 $115 \%$ 수준으로 고설재배 면적이 증가하고 있다(Ko 2015). 이러한 영농기술 변화에 따라 농가현장에서는 침투이행성 농약을 관주 처리로 살포하고 있지 만, 현재 각 수출국별 관주 처리로 등록된 농약의 비율은 4-7\% 수준으로 매우 부족한 실정이다(RDA 2016). 농약안전사용지침 에서 관주 처리로 등록되지 않은 농약을 사용하는 것은 농약관 리법에 위반되므로 사용이 금지되고 있다. 하지만 농가에서는 관주 처리 농약살포 방법이 노동력 절감효과가 있고, 병해충 방 제에도 효과적이어서 계속적으로 사용하고 있는 실정이다.

이러한 상황을 반영하여 본 연구에서는 시설 양액재배 딸기 중 관주 처리 농약의 등록 확대를 위한 기초자료로 활용할 수 있도록 침투성 농약의 경시적 잔류특성 연구를 수행하였다. 시 험약제는 잿빛곰팡이병 및 탄저병 예방을 위해 많이 사용하는 azoxystrobin 및 carbendazim을 선정하였으며, 관주 처리법의 안 전성 구명을 위해서 고설재배하는 딸기 농가에 시험농약을 경 엽 및 관주 처리 하였을 때 농약살포 후 처리시간에 따른 잔류 량 비교시험을 진행하였다.

\section{재료 및 방법}

\section{시험농약}

Azoxystorobin의 표준품(99.5\%), carbendazim의 표준품(99.0\%) 는 모두 Dr. Ehrenstorfer GmbH (Augsburg, Germany)에서 구 입하여 사용하였다. Azoxystrobin과 carbendzim은 acetonitrile (Merck, Darmstadt, Germany), methanol (Merck)으로 각각 $1,000,200 \mathrm{mg} / \mathrm{L}$ stock solution을 제조한 다음 이를 살포용 농 약은 azoxystrobin $21.7 \%$ 액상수화제 및 carbendazim $60 \%$ 수 화제를 이용하였다. 두 약제의 화학구조식과 이화학적 성질은 Table 1과 같다.

\section{시험작물 및 포장시험}

딸기는 ‘매향'(Fragarid X ananassa Duch 'Maehyang')품종으로 경남 진주시 수곡면에 위치한 시설양액재배 농가에서 시험을 진 행하였다. 시험기간은 2016년 4월 4일부터 27일까지 진행하였 다. 시험농약 azoxystroboin, carbendazim은 각각 경엽 및 관주 처리 와 농약안전사용기준 및 2 배수 농도처리구별로 실험을 진 행하였다. 경엽 처리는 약액이 충분히 젖을 정도로 살포하였고,
Table 1 Physicochemical properties of azoxystrobin and carbendazim

\begin{tabular}{ccc}
\hline & Carbendazim \\
Chemical structure & & \\
& 403.4 & 191.2 \\
Mol. wt. & $1.1 \times 10^{-7} \mathrm{mPa}^{\circ}\left(20^{\circ} \mathrm{C}\right)$ & $0.09 \mathrm{mPa}\left(20^{\circ} \mathrm{C}\right)$ \\
V.p. $(\mathrm{mPa})$ & $2.5\left(20^{\circ} \mathrm{C}\right)$ & $1.51(\mathrm{pH} 7)$ \\
$\mathrm{K}_{\text {ow }} \operatorname{logP}$ & $6 \mathrm{mg} / \mathrm{L}$ & $29 \mathrm{mg} / \mathrm{L}$ \\
Solubility in water &
\end{tabular}

관주 처리는 근부 부위에 1주당 $100 \mathrm{~mL}$ 씩 투여하였다. 딸기에 농약살포 후 0 (2시간 후), $3,6,9,12,16,21$ 일에 병·해충 피 해가 없고 상품성이 있는 딸기를 채취하였고, 시험샘플은 꼭지 를 제거한 딸기 및 딸기잎을 폴리에틸렌 비닐에 담은 후 신속 히 실험실로 운반하여 분석까지 $-20{ }^{\circ} \mathrm{C}$ 이하에서 보관하였다. 잔류농약 분석 전 시험샘플을 드라이아이스와 함께 분쇄하여 분 석샘플로 이용하였다.

\section{잔류농약 분석}

딸기 $20 \mathrm{~g}$ 을 칭량한 후 methanol $60 \mathrm{~mL}$ 를 첨가한 후 $250 \mathrm{rpm}$ (Combi-shakerNB-101MT, N-Biotek, Bucheon, Korea)에서 30 분 동안 진탕하였다. 추출한 시료를 감압여과한 후 포화식염수 $20 \mathrm{~mL}$, 증류수 $200 \mathrm{~mL}$ 를 첨가하여 dichloromethane (Merck) $100,50 \mathrm{~mL}$ 로 2 회 분배한 후 분배액을 농축하여 $5 \mathrm{~mL} \mathrm{n}$-hexane: acetone $(95: 5, \mathrm{v} / \mathrm{v})$ 혼합용매로 재용해 하였다. Florisil (FL) cartridge $(1 \mathrm{~g})$ 을 이용하여 Solid Phase Extraction (SPE) 정제 작업을 진행하였다. $\mathrm{FL}$ cartridge에 n-hexane으로 $5 \mathrm{~mL}$ 로 conditioning한 후, 시료 추출액 $5 \mathrm{~mL}$ 를 loading하고, 1 차 전개 액 (n-hexane : acetone $=90: 10, \mathrm{v} / \mathrm{v}$ )을 $5 \mathrm{~mL}$ 흘려버리고, 2차 전개액(n-hexane : acetone $=70: 30, \mathrm{v} / \mathrm{v}) 20 \mathrm{~mL}$ 를 이용하여 용 출하였다. 용출액을 $40{ }^{\circ} \mathrm{C}$ 이하에서 감압농축하여 $10 \mathrm{~mL}$ acetonitrile로 재용해 한 후 UHPLC/PDA를 이용하여 분석하였 다(Table 2).

딸기잎 $5 \mathrm{~g}$ 을 $50 \mathrm{~mL}$ plastic tube에 칭량 후 $15 \mathrm{~mL} 1 \%$ acetic acid가 포함된 acetonitrile를 첨가한 후 $1300 \mathrm{rpm}$ (1600 MiniG, SPEX sample Prep, Metuchen, NJ, USA) 5분동안 진탕하였다. 진탕 후 Agilent QuEChERS Extract kit AOAC 2007. 01 (6g magnesium sulfate $\left(\mathrm{MgSO}_{4}\right), 1.5 \mathrm{~g}$ sodium acetate $\left.(\mathrm{NaOAc})\right)$

Table 2 LC and LC-MS/MS conditions for analyzing the pesticides

\begin{tabular}{ccc}
\hline \hline & Azoxystrobin & Carbendazim \\
Instrument & UHPLC-PDA & HPLC-UVD \\
Column & (Shimadzu Nexera X2, Japan) & (Agilent 1100 HPLC system, USA) \\
Luna $5 \mu$ C18 $(2)$, & $250 \times 4.60 \mathrm{~mm}, 5 \mathrm{micron}$ \\
Mobile phase & Shim-pack GIS-ODS & Water/Acetonitrile=40:60 (v/v) \\
Column temperature & $3 \mu \mathrm{m}, 100 \times 0.3 \mathrm{~mm}, \mathrm{id}$ & $40{ }^{\circ} \mathrm{C}$ \\
Wave length & Water/Acetonitrile=50:50 $(\mathrm{v} / \mathrm{v})$ & $220 \mathrm{~nm}$ \\
Injection volume & $40{ }^{\circ} \mathrm{C}$ & $10 \mu \mathrm{L}$ \\
Flow rate & $250 \mathrm{~nm}$ & $5 \mu \mathrm{mL} / \mathrm{min}$ \\
\hline
\end{tabular}


를 첨가한 후 $1300 \mathrm{rpm}, 30$ 초간 흔든 다음 $3500 \mathrm{rpm}$ (Combi514R, Hanil, Gimpo, Korea)에서 5분간 원심분리하여 상징액 8 $\mathrm{mL}$ 를 취하였다. 상징액 $8 \mathrm{~mL}$ 를 Agilent QuEChERS dispersive kit $15 \mathrm{~mL}(1200 \mathrm{mg} \mathrm{MgSO}$, $400 \mathrm{mg}$ PSA)에 첨가한 후 2분 간 voltex mixer를 이용하여 흔든 다음 $3500 \mathrm{rpm}$, 5분간 원심 분리 하였다. 원심분리된 시료의 상징액 $4 \mathrm{~mL}$ 를 감압농축 한 후 딸기에서 $\mathrm{FL}$ 을 이용한 $\mathrm{SPE}$ 정제과정을 위의 실험과정과 동 일하게 진행한 후 acetonitrile $4 \mathrm{~mL}$ 로 재용해한 후 UHPLC/ $\mathrm{PDA}$ 를 이용하여 분석하였다(Table 2).

딸기 $20 \mathrm{~g}$ 을 칭량한 후 methanol $60 \mathrm{~mL}$ 를 첨가한 후 $250 \mathrm{rpm}$ (Combi-shakerNB-101MT, N-Biotek, Bucheon, Korea)에서 30 분동안 진탕한 후 감암여과 하였다. 감압여과한 시료를 포화식 염수 $20 \mathrm{~mL}$, 증류수 $200 \mathrm{~mL}$ 와 함께 $500 \mathrm{~mL}$ 분액여두에 옮긴 후, $1 \mathrm{~N} \mathrm{HCl}$ 를 첨가하여 $\mathrm{pH}$ indicator strip (Merck)를 이용해 $\mathrm{pH}$ 2-3수준으로 조절하였다. Dichloromethane $100,50 \mathrm{~mL}$ 로 2 회 추출하여 흘려버리고, 수용액 층을 $1 \mathrm{~N} \mathrm{NaOH}$ 를 이용하여 위와 동일한 방법으로 $\mathrm{pH}$ 7-8로 조절하였다. Dichloromethane $100,50 \mathrm{~mL}$ sodium sulfate를 통과시킨 후 $40^{\circ} \mathrm{C}$ 이하에서 감 압농축 하였고, 농축한 시료를 $10 \mathrm{~mL}$ acetonitrile에 재용해 하 여 $\mathrm{HPLC} / \mathrm{UVD}$ 에 최종분석 하였다(Table 2).

딸기잎 $5 \mathrm{~g}$ 을 $50 \mathrm{~mL}$ plastic tube에 칭량 후 $15 \mathrm{~mL} 1 \%$ acetic acid가 포함된 acetonitrile를 첨가한 후 $1300 \mathrm{rpm}, 5$ 분동안 진탕 하였다. 진탕 후 $\mathrm{QuEChERS} \mathrm{Extract} \mathrm{kit를} \mathrm{첨가한} \mathrm{후} 1300$ $\mathrm{rpm}, 30$ 초간 흔든 다음 $3500 \mathrm{rpm}$ 에서 5 분간 원심분리하여 상징 액 $1 \mathrm{~mL}$ 를 취하였다. 채취한 상징액을 $\mathrm{AOAC}$ 2007. 01. (150 $\left.\mathrm{mg} \mathrm{MgSO}_{4}, 50 \mathrm{mg} \mathrm{GCB}, 50 \mathrm{mg} \mathrm{PSA}\right)$ 방법을 이용하여 들어 있는 $2 \mathrm{~mL}$ 원심분리관에 넣어 30 초간 voltex mixer를 이용하여 흔든 다음 $12000 \mathrm{rpm}$ 의 속도로 5 분간 원심분리 하였다. 원심분 리된 시료의 상징액 $500 \mu \mathrm{L}$ 를 채취한 후 $500 \mu \mathrm{L}$ 의 $0.1 \%$ formic acid를 함유한 acetonitrile이 들어있는 $2 \mathrm{~mL}$ vial에 옮긴 다음 HPLC-MS/MS로 분석하였다(Table 3).

\section{표준검량선 작성 및 회수율 시험}

표준검량선 작성을 위해서 working solution을 희석하여 $\mathrm{LC}$ 는 $0.05,0.1,0.2,0.5,1.0,2.0,5.0 \mathrm{mg} / \mathrm{kg}$ 의 용액을 만들었고, LC-MS/MS는 $0.01,0.05,0.1,0.2,0.5 \mathrm{mg} / \mathrm{kg}$ 수준으로 무처리 시료를 이용해 희석하여 matrix matched 표준용매를 만들어서 Table 2-4의 기기분석조건에서 나타난 chromatography상의 peak 면적을 기준으로 검량선을 작성하였다. 기기의 정량한계를 파악 하기 위해서 $\mathrm{LC}$ 에서 $0.01,0.025,0.05,0.1 \mathrm{mg} / \mathrm{kg}, \mathrm{LC}-\mathrm{MS} /$ $\mathrm{MS}$ 에서는 $0.005,0.01,0.025,0.05 \mathrm{mg} / \mathrm{kg}$ 표준용액을 기기에 주입하여 $\mathrm{S} / \mathrm{N}$ ratio가 3 이상 일때를 검출한계, 10 이상일 때 정량한계로 설정하였다. 또한 위의 농도의 peak 면적 값을 이 용해 검량선의 직선성을 평가하였다.

시험농약에 사용된 azoxystrobin, carbendazim 회수율 시험을 위 해 무처리 시료에 표준용액 $10 \mathrm{mg} / \mathrm{kg}$ 을 이용하여 $0.5,2.5 \mathrm{mg} / \mathrm{kg}$ 수준으로 첨가하였다 $(n=3)$. 표준용액 첨가 후 무처리 시료와 혼 합 후 30 분간 방치한 후 상기의 방법으로 회수율을 산출하였다.

\section{반감기 및 회귀식 산출 방법}

딸기 중 경엽처리 하였을 때 azoxystrobin, carbendazim의 잔류 량은 표준검량선을 적용하여 산출하였으며, 생물학적 반감기는
Table 3 LC-MS/MS conditions for analyzing carbendazim in strawberry leaves

\begin{tabular}{|c|c|c|c|}
\hline Instrument & \multicolumn{3}{|c|}{$\begin{array}{l}\text { Agilent } 1200 \mathrm{HPLC} \text { with Agilent } 6410 \text { triple- } \\
\text { quadrupole MS }\end{array}$} \\
\hline Column & \multicolumn{3}{|c|}{ YMC-Pack Pro C18 RS $100 \times 3$ mm I.d, $3 \mu \mathrm{m}$} \\
\hline Mobile nhase & \multicolumn{3}{|c|}{ A: Water with $0.1 \%$ formic acid } \\
\hline & \multicolumn{3}{|c|}{ B: Acetonitrile with $0.1 \%$ formic acid } \\
\hline \multirow{6}{*}{ Gradient table } & Time (min) & $\mathrm{A}(\%)$ & $\mathrm{B}(\%)$ \\
\hline & 0 & 95 & 5 \\
\hline & 2 & 30 & 70 \\
\hline & 5 & 30 & 70 \\
\hline & 8 & 95 & 5 \\
\hline & 9 & 95 & 5 \\
\hline Flow rate & \multicolumn{3}{|c|}{$0.2 \mathrm{~mL} / \mathrm{min}$} \\
\hline Column temp. & \multicolumn{3}{|c|}{$40^{\circ} \mathrm{C}$} \\
\hline Injection volumn & \multicolumn{3}{|c|}{$10 \mu \mathrm{L}$} \\
\hline Ionization mode & \multicolumn{3}{|c|}{ ESI Positive } \\
\hline Scan type & \multicolumn{3}{|c|}{ MRM } \\
\hline Compound name & $\begin{array}{l}\text { Precursor ion } \\
(\mathrm{m} / \mathrm{z})\end{array}$ & Quantifier & Qualifier \\
\hline Carbendazim & 192.1 & 160.1 & 132.1 \\
\hline
\end{tabular}

산출된 잔류량 데이터를 Excel(Microsoft Excel 2010, Redmond, WA, USA)을 이용하여 그래프를 작성 후 first order kinetics에 의한 지수감소식을 유도하여 $\mathrm{k}$ 값 산출 후 생물학적 반감기를 산출하였다.

\section{결과 및 고찰}

\section{딸기 중 시험농약의 정량한계 및 희수율}

딸기 및 딸기잎 중 azoxystrobin, carbendazim의 표준검량선을 작성하기 위해 $\mathrm{LC}$ 및 $\mathrm{LC}-\mathrm{MS} / \mathrm{MS}$ 를 이용하였다. 검량선의 결 정계수 $\left(\mathrm{R}^{2}\right)$ 는 0.99 이상으로 양호한 직선성을 나타내었고, 시험 농약의 정량한계(limit of quantitaion, LOQ)는 $0.01-0.05 \mathrm{mg} / \mathrm{kg}$ 수준이었다. 딸기 중 시험농약의 회수율은 73.4-100.6\% 수준이 었다(Table 4).

\section{딸기 중 침투성 농약 경엽 처리시 농약 잔류특성}

딸기 중 azoxystrobin은 농약 살포 후 0-21일 동안 잔류량 농약 사용기준과 두배처리구에서 각각 $0.1-1.7,0.3-5.0 \mathrm{mg} / \mathrm{kg}$ 수준이 었다(Fig. 1). 회귀식을 이용하여 딸기 중 azoxystrobin의 반감 기는 4.8 및 5.7일이었다. 이와 같은 결과는 Angioni 등(2004) 의 플라스틱 터널에서 재배하는 딸기 중 azoxystrobin 잔류량 경감연구에서는 5 월달 $0-15$ 일 동안 딸기 중 azoxystrobin 잔류 량은 $0.2-0.6 \mathrm{mg} / \mathrm{kg}$ 수준이었고, 회귀식을 이용하여 산출한 반 감기는 7.8일로 본 연구결과와 다소 차이가 있었다. 본 연구의 결과는 Angioni 등(2004)의 연구는 농약살포를 $0.1 \mathrm{~g} / \mathrm{L}$ 수준으 로 살포하였고 본 연구는 각각 $0.2,0.4 \mathrm{~g} / \mathrm{L}$ 수준으로 유효성분 의 차이로 인해 잔류량의 차이가 발생한 것으로 판단된다. 또 한 농약분해는 빛 및 기온에 의해 잔류분해 속도가 다르게 나 타나는데 이러한 요인의 조건이 달라서 분해속도가 다르게 나 
Table 4 Recoveries of pesticides in strawberry fruits and leaves

\begin{tabular}{|c|c|c|c|c|c|c|c|}
\hline \multirow{2}{*}{ Pesticide } & \multirow{2}{*}{ Substrate } & \multicolumn{2}{|c|}{ Low $(0.5 \mathrm{mg} / \mathrm{kg})$} & \multicolumn{2}{|c|}{ High $(2.5 \mathrm{mg} / \mathrm{kg})$} & \multirow{2}{*}{$\mathrm{R}^{2}$} & \multirow{2}{*}{$\begin{array}{c}\text { LOQ } \\
(\mathrm{mg} / \mathrm{kg})\end{array}$} \\
\hline & & Recovery(\%) & $\operatorname{RSD}(\%)$ & Recovery(\%) & $\operatorname{RSD}(\%)$ & & \\
\hline \multirow{2}{*}{ Azoxystrobin } & Strawberry fruits & $73.4 \pm 3.8$ & 5.1 & $100.6 \pm 14.4$ & 14.3 & 0.999 & \multirow{2}{*}{0.05} \\
\hline & Leave & $76.4 \pm 3.8$ & 5.0 & $81.4 \pm 7.5$ & 9.3 & 0.999 & \\
\hline \multirow{2}{*}{ Carbendazim } & Strawberry fruits & $91.2 \pm 2.4$ & 2.7 & $86.1 \pm 9.2$ & 10.7 & 0.999 & 0.05 \\
\hline & Leaves & $81.3 \pm 3.3$ & 4.1 & $83.5 \pm 3.7$ & 4.5 & 0.999 & 0.01 \\
\hline
\end{tabular}
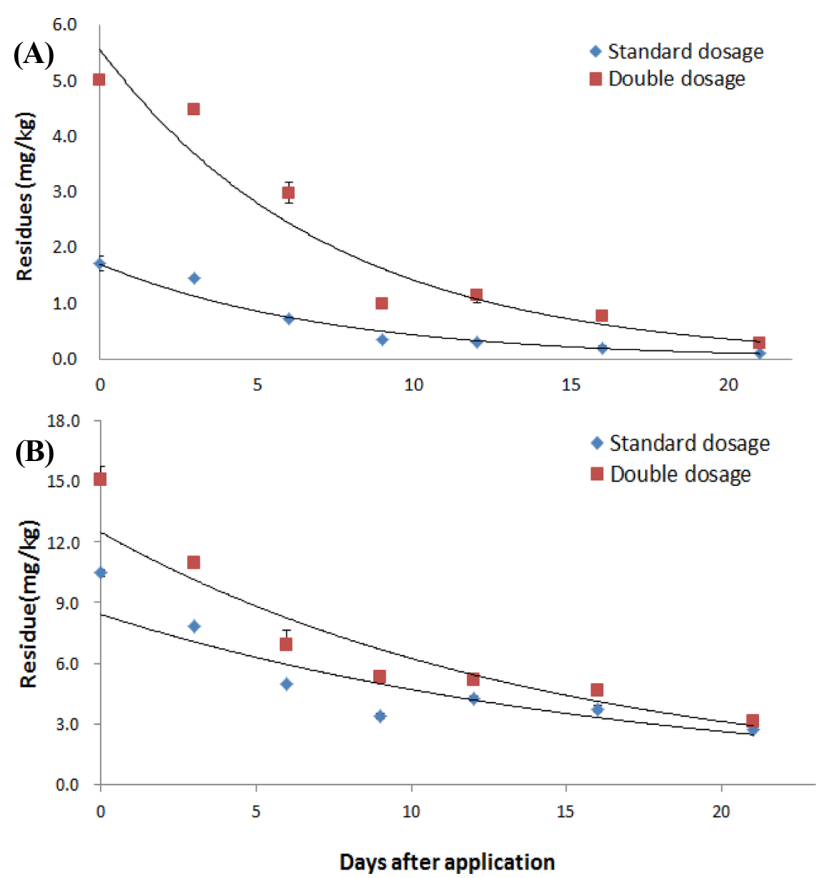

Fig. 1 Residue pattern after foliar application of pesticides in strawberry fruits. (A) azoxystrobin, (B) carbendazim

타난 것으로 판단된다(Kwon 등, 2004). 또한 재배방식의 차이 로 인해 잔류양상이 다르게 나타나는데, 플라스틱 터널에서의 토경재배와 시설재배의 고설재배 방식의 차이가 영향을 미친 것 으로 판단된다. Lee 등(2011) 의 보고에서도 포도의 시설재배와 비가림재배 중 azoxystrobin의 잔류량 비교에서 농약의 반감기 는 비가림재배에서 15.6일, 시설재배에서 13.3일로 차이를 나타 나는 것을 확인했다.

딸기 중 azoxystrobin의 21일 동안 분해율은 기준량 및 2 배 처리구에서 94 및 $96 \%$ 로 처리배수에 관계없이 21일 후에 $90 \%$ 이상 농약이 분해되는 것을 확인하였다. Lee 등(2013)의 매실 중 azoxystrobin의 잔류특성 연구에서 농약안전사용기준 표 준량 농약살포 10 일 후 약 $60 \%$ 분해되었고, 본 연구에서는 12 일 후 $80 \%$ 분해되므로, 딸기에서 azoxystrobin이 더 빠른 분해 속도가 나타내는 것을 확인하였다.

Carbendazim은 초기 농약살포 후 0-21일 동안 처리농도별 잔 류량은 기준처리구와 배량처리구에서 각각 $2.8-10.5,3.2-15.1$ $\mathrm{mg} / \mathrm{kg}$ 이었고 21 일 이후 초기량 대비 각각 $75,79 \%$ 수준으로 경감되는 것으로 확인되었다. 딸기 중 carbendazim의 반감기는 회귀식으로 산출하였을 때 표준량 및 배량 처리구에서 9.3 및
8.4일이었다. $\mathrm{Li}$ 등(2016)은 중국에서 서로 다른 세 지역에서 토 마토 중 carbendazim의 잔류양상 연구를 진행하였는데, 반감기 가 $2.1,2.2,3.8$ 일로 산출되고, 초기 잔류량은 $0.5-0.8 \mathrm{mg} / \mathrm{kg}$ 수 준으로 나타났다. Lee 등(2017)은 작물 표면의 융모는 표면적 을 증가시켜 융모가 있는 작물은 융모가 존재하지 않는 작물에 비해 5.4배 높은 잔류량을 가진다고 보고하였다. 딸기는 융모로 인해 표면적이 커서 초기잔류량이 토마토에 비하여 높은 것으 로 사료된다. 또한 반감기가 다르게 나타난 것은 초기잔류량과, 실험시기 및 재배환경 차이 때문으로 판단된다.

\section{딸기 중 침투성 농약 관주 처리시 농약 잔류특성}

딸기 중 관주 처리 하였을 때 농약 잔류량은 azoxystrobin에서는 배량 처리구의 9일차에서 $0.1 \mathrm{mg} / \mathrm{kg}$ 수준으로 검출되었고, 나머 지 실험조건에서는 모두 불검출 되었다. 딸기에서 azoxystrobin 은 탄저병 방제를 위해 관주처리로 관행적으로 살포 되어지는 데 azoxystrobin을 관주 처리 하여 표준량의 2 배로 처리하여도 딸기 중 최고농도가 $0.1 \mathrm{mg} / \mathrm{kg}$ 으로 국내 잔류허용기준(Maximum Residue Limit, MRL)인 $1.0 \mathrm{mg} / \mathrm{kg}$ 보다 낮은 수준으로 검출되기 때문에 농약 안전성에 문제가 없을 것으로 보여진다.

딸기 중 carbendazim을 관주 처리를 이용하여 살포한 후 0 21일 동안 잔류량이 N.D.- $1.1 \mathrm{mg} / \mathrm{kg}$ 수준으로 나타났다. 처리농 도에 관계없이 9일차까지 농도가 증가한 후 농약이 분해되지 않고 비슷한 농도 수준으로 유지되는 것으로 나타났다(Fig. 2). 위의 결과를 통해서 딸기에서 농약 관주 처리 9일 후에 최고농 도로 검출되는 것으로 판단된다.

관주 처리 하였을 때 침투성농약의 이행성을 확인하기 위해 딸기잎에서 잔류량을 조사하였다. 딸기잎 중 azoxystrobin 잔류 량은 살포 후 0-21일 동안 N.D.-4.8 mg/kg 수준으로 나타났고, carbedazim은 N.D.-21.96 mg/kg 수준이었다. 본 연구에서 딸기 에 중 잔류량은 carbendazim이 높게 나타났는데, 이러한 결과 를 통해 carbendazim의 이행성이 더 높은 것으로 판단된다. Azoxystrobin 보다 높은 유효성분 함량이 잔류량을 높게 나타 내는 요인이기도 하지만, Ihm 등(2002)은 작물체내에서 농약의 이행성은 옥탄올-물 분배계수와 연관이 있다고 보고하였다. Carbendazim은 azoxystrobin다 $\mathrm{K}_{\mathrm{ow}}$ 값이 낮아 상대적으로 극성 성분을 가지며, 물에 대한 용해도가 높기 때문이다. 그러므로 뿌리를 통해 흡수된 농약이 물관부를 통해 가식부로 이동하게 되는데 상대적으로 극성이고 물에 대한 용해도가 높은 carbendazim이 이 경로를 통해 작물체내에서 더 높은 이행성을 가지는 것으로 판단된다.

Carbendazim을 관주 처리 하였을 때 잔류량이 10 일 후에도 분해되지 않는 것은 딸기잎에 잔류된 농약이 딸기로 이행되기 때문이다. Park과 $\operatorname{Kim}(2011)$ 의 고추 부위별 카벤다짐의 잔류양 

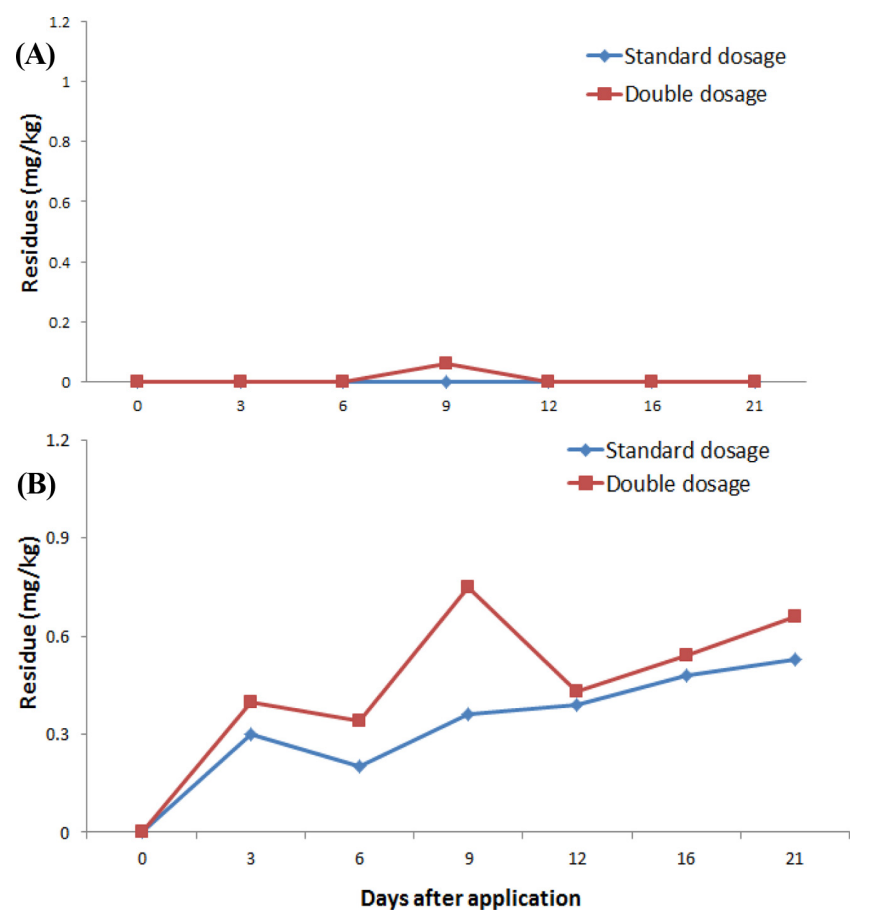

Fig. 2 Residue pattern after drenching of pesticides in strawberry fruits. (A) azoxystrobin, (B) carbendazim

상 연구에서도 고추잎에서 고추로 침투성 농약이 이행되어, 시 간이 지날수록 고추와 고추잎 간의 농약성분함량 비율이 고추 가 더 높아지는 것으로 나타났다.

\section{딸기 중 농약 처리방법에 따른 잔류량 비교}

관주 처리한 침투성 농약의 안전성을 평가하기 위해서 경엽 및 관주 처리 하였을 때 농약 잔류량 비교시험을 진행하였다. 딸 기 중 농약 잔류량은 경엽 처리에서 더 높은 것으로 나타났다 (Table 6).

딸기 중 azoxystrobin의 잔류량 비교에서 관주 처리한 딸기에서 농약이 불검출 되었기 때문에 처리방법에 따른 잔류량 비교를 할 수 없었다. 그러나 딸기 중 농약 관주 처리는 경엽 처리때 보다 잔류량이 낮았기 때문에 관주 처리 잔류농약 안전성 측면에서 더 안전한 것으로 판단된다. 농약을 관주 처리 하였을 때 잔류량이 낮은 이유는 경엽 처리와 달리 직접적으로 살포하지 않기 때문이 다. 또한 농약을 관주 처리 할 때 상토 중의 수분에 의해 희석되 기 때문에 잔류량이 더 낮게 나타나는 것으로 판단된다.

Carbendazim은 시험기간 동안 농약 처리방법에 따른 잔류량 을 비교하였을 때 5-27배 차이를 나타냈다. Ahn 등(2007)의 연 구에서 배추에 trifloxystrobin을 경엽 및 토양 관주 처리하였을 때 잔류량이 경엽 처리에서는 $17.5-23.5 \mathrm{mg} / \mathrm{kg}$ 수준이었고, 관 주 처리하였을 때 $0.2-0.3 \mathrm{mg} / \mathrm{kg}$ 로 $78-88$ 배 정도 잔류량 차이가 발생하였다.

농약 처리방법에 따른 carbendazim의 잔류량 비교에서 처리 시간이 지날수록 잔류량 차이가 줄어들었다. 농약을 경엽 처리 하여 살포시 상당 부분의 농약이 작물표면에 잔류되어 분해속 도가 빠르지만 관주 처리를 통해 작물체내에 잔류된 농약은 분 해속도가 느리기 때문에(Mohapatra와 Lekha 2016), 처리시간이
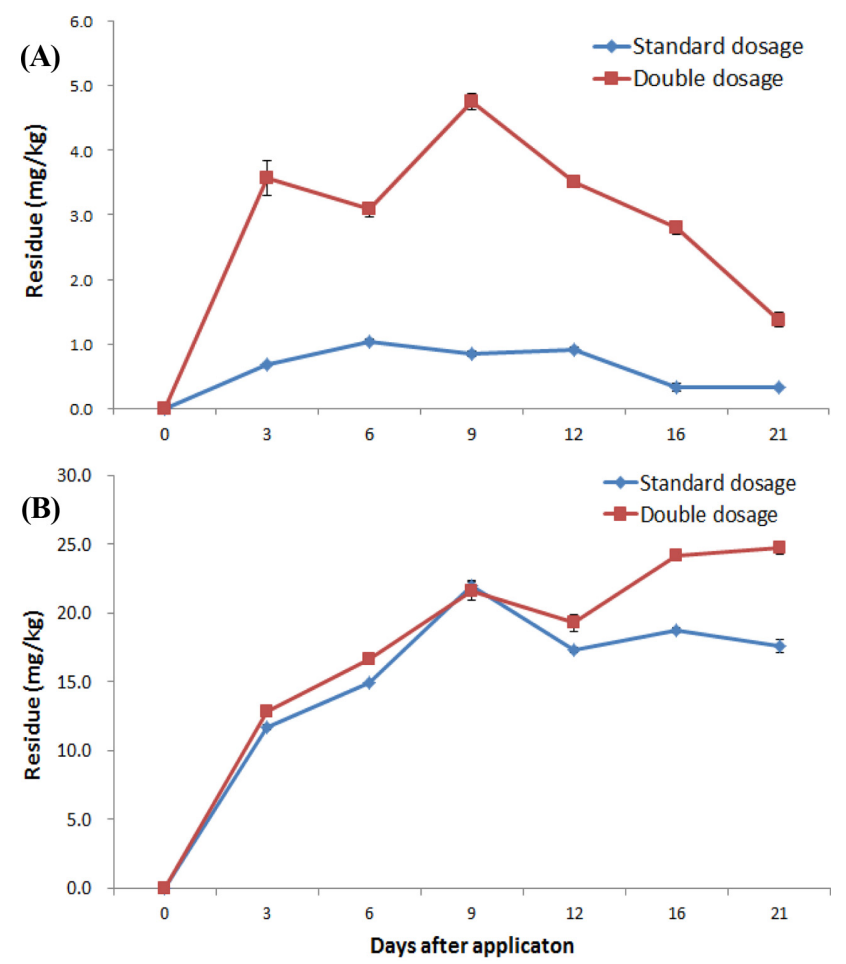

Fig. 3 Residue pattern after drenching of pesticides in strawberry leaves. (A) azoxystrobin, (B) carbendazim

Table 5 The degradation kinetics and half-lives of azoxystrobin and carbendazim

\begin{tabular}{ccccc}
\hline \hline Pesticide & Dosage & $\begin{array}{c}\text { Regression } \\
\text { equation }\end{array}$ & $\mathrm{R}^{2}$ & $\begin{array}{c}\text { Half-life } \\
\text { (days) }\end{array}$ \\
\hline \multirow{2}{*}{ Azoxystrobin } & Standard & $\mathrm{y}=1.71 \mathrm{e}^{-0.14 \mathrm{x}}$ & 0.97 & 4.8 \\
& Double & $\mathrm{y}=5.57 \mathrm{e}^{-0.14 \mathrm{x}}$ & 0.94 & 5.7 \\
\hline \multirow{2}{*}{ Carbendazim } & Standard & $\mathrm{y}=8.42 \mathrm{e}^{-0.06 \mathrm{x}}$ & 0.81 & 9.3 \\
& Double & $\mathrm{y}=12.49 \mathrm{e}^{-0.07 \mathrm{x}}$ & 0.91 & 8.4 \\
\hline
\end{tabular}

지나면서 잔류량 차이가 줄어드는 것으로 판단된다. Juraske 등 (2009) 의 토마토 중 imidacloprid를 농약 처리방법에 따른 잔 류양상 연구에서도 본 연구와 비슷한 양상을 나타냈다. 경엽 처 리 하였을 때 imidacloprid의 초기 잔류량이 $1.6 \mathrm{mg} / \mathrm{kg}$ 에서 28 일 후 $0.2 \mathrm{mg} / \mathrm{kg}$ 경감되었고, 관주 처리한 토마토에서는 처리 후 13 일 후 $0.2 \mathrm{mg} / \mathrm{kg}$ 으로 가장 높은 농도가 검출된 후 28 일 후 $0.1 \mathrm{mg} / \mathrm{kg}$ 수준으로 검출되었다. Juraske 등(2009)의 연구에 서도 처리 방법별 최고 농도의 차이는 8 배 수준이었는데, 28 일 후 잔류량은 약 1.5 배 정도 수준으로 잔류량 차이가 줄어들었다. 본 연구와 Juraske 등(2009)의 연구에서도 관주 처리 하였을 때 처리시간 별로 잔류량이 더 낮아서 안전성 부분에서 관주 처리가 더 좋은 것으로 판단된다. 농약을 관주 처리 할 때 농 약 잔류량이 낮아서 안전하지만 관주 처리로 등록되지 않은 농 약을 관주 처리 하여 살포하는 것은 농약관리법 위반이므로 농 업현장에서 안전하게 사용될 수 있도록 관주 처리 등록 농약이 확대되어야 할 것이다. 또한 관주 처리한 농약은 잔류량은 낮 을 수 있으나 분해속도가 느리기 때문에 MRL이 낮은 농약을 사용할 경우 주의가 필요하다. 
Table 6 Residual difference of azoxystrobin and carbendazim in strawberry fruits

\begin{tabular}{|c|c|c|c|c|c|c|c|c|c|}
\hline \multirow{2}{*}{ Pesticide } & & \multirow{2}{*}{ Treatments } & \multicolumn{7}{|c|}{ Days after application } \\
\hline & & & 0 & 3 & 6 & 9 & 12 & 16 & 21 \\
\hline \multirow{6}{*}{ Azoxystrobin } & \multirow{3}{*}{$\begin{array}{c}\text { Standard } \\
\text { dosage }\end{array}$} & Foliar application & 1.7 & 1.5 & 0.7 & 0.4 & 0.3 & 0.2 & 0.1 \\
\hline & & Drenching & N.D. ${ }^{1)}$ & N.D. & N.D. & N.D. & N.D. & N.D. & N.D. \\
\hline & & Residual difference & & & & & & & \\
\hline & \multirow{3}{*}{$\begin{array}{c}\text { Double } \\
\text { dosage }\end{array}$} & Foliar application & 5.0 & 4.5 & 3.0 & 1.0 & 1.1 & 0.8 & 0.3 \\
\hline & & Drenching & N.D. & N.D. & N.D. & 0.1 & N.D. & N.D. & N.D. \\
\hline & & Residual difference & & & & 17 & & & \\
\hline \multirow{6}{*}{ Carbendazim } & \multirow{3}{*}{$\begin{array}{c}\text { Standard } \\
\text { dosage }\end{array}$} & Foliar application & 10.5 & 7.9 & 5.0 & 4.7 & 4.3 & 3.4 & 2.8 \\
\hline & & Drenching & N.D. & 0.3 & 0.2 & 0.4 & 0.4 & 0.5 & 0.5 \\
\hline & & Residul difference & & 26 & 25 & 13 & 11 & 7 & 5 \\
\hline & \multirow{3}{*}{$\begin{array}{l}\text { Double } \\
\text { dosage }\end{array}$} & Foliar application & 15.1 & 11.0 & 6.9 & 6.7 & 5.3 & 5.2 & 3.2 \\
\hline & & Drenching & N.D. & 0.4 & 0.3 & 0.8 & 0.4 & 0.5 & 0.7 \\
\hline & & Residul difference & & 27 & 20 & 9 & 12 & 10 & 5 \\
\hline
\end{tabular}

Not Detected

\section{초 록}

딸기는 한국의 주요 농산물 중 하나로 매년 3,000 만 달러 이상 이 수출된다. 그러나 농산물 안전은 최근 농업 무역에서 중요 한 요소로 작용하고 있어, 안전한 농산물을 생산하는 것은 매 우 중요하다. 안전한 농산물을 생산하려면 적절하게 농약을 관 리하는 것이 필수적이다. 딸기는 고설재배를 이용해 경작하는 곳이 많아지고 있는데 점적관수를 이용해 수분, 양분 및 농약 을 관주 처리하여 투여하고 있다. 농약을 살포 할 때 관주 처 리는 경엽처리를 사용하는 것보다 잔류농약 수준이 더 낮게 나 타났다. 본 연구에서는 딸기 중 농약을 관주처리 및 경엽처리 하였을 때, 농약의 잔류량을 경시적으로 비교 하였다. 농약을 농약안전사용기준량 및 두배량으로 처리 한 후 $0,3,6,9,13$, 16 및 21 일에 수집한 후 $-18{ }^{\circ} \mathrm{C}$ 에서 보관 하였다. 샘플을 $\mathrm{LLE}$ (액체-액체 추출) 및 $\mathrm{QuEChERS}$ 의 전처리 후 LC 및 LC-MS/ $\mathrm{MS}$ 로 분석 하였다. 결과적으로 관주 처리 한 딸기는 모든 처 리구에서 $1 \mathrm{mg} / \mathrm{kg}$ 미만으로 검출되었다. 농약을 경엽 처리와 관 주 처리 하였을 때 딸기의 잔류량 차이는 carbendazim의 경우 5-27배 정도 경엽처리가 높았고, azoxystrobin은 관주처리 시 불 검출 되어 비교할 수 없었다.

Keywords 관주 처리 · 경엽 처리 · 딸기 · Azoxystrobin · Carbendazim

감사의 글 본 연구는 농촌진흥청 국립농업과학원 농업과학기술 연구개발 사업(과제번호: PJ01131204)의 지원에 의해 이루어진 것임.

\section{References}

Ahn XH, Lee SB, An WH, Kim JD (2007) Risk Assessment of Trifloxystrobin in Chinese Cabbage by Foliar Application and Drenching. The Korean J Pestic Sci 11(1): 21-27

Angioni A, Schirra M, Garau VL, Melis M, Tuberoso CIG, Cabras P (2004) Residues of azoxystrobin, fenhexamid and pyrimethanil in strawberry following field treatments and the effect of domestic washing. J Food
Additives \& Contaminants 21(11): 1065-1070

Ayala-Zavala JF, Wang SY, Wang CY, Gonza'lez-Aguilar GA (2004) Effect of storage temperatures on antioxidant capacity and aroma compounds in strawberry fruit. Swiss Soc Food Sci Technol 37: 687-695

Azodanlou R, Darbellay C, Luisier J, Villettaz J, Amado R (2003) Quality assessment of strawberries (Fragaria species). J Agric Food Chem 51: $715-721$

Cho JI, Ha SD, Kim KS (2004) Inhibitory effects of temperature, pH, and potassium sorbate against natural microflora in strawberry paste during storage. Korean J Food Sci Technol 36: 355-360

Ihm YB, Lee JS, Kyung KS, Kim CS, Oh KS, Jin YD, Lee BM (2002) Control of Phythophthora capsici and residual characteristics by drenching of pesticides on tomato in hydroponic culture system. The Korean J Pestic Sci 6(4): 287-292

Juraske R, Castells F, Vijay A, Munoz P, Anton A (2009) Uptake and persistence of pesticides in plants: Measurements and model estimates for imidacloprid after foliar and soil application. J Harzard Mater 165: 683-689

Kim YH, Lee IB, Chun CH, Hwang HS, Hong SW, Seo IH, Yoo JI, Bitog JP, Kwon KS (2009) Utilization of $\mathrm{CO}_{2}$ Influence by windbreak in an elevated production system for strawberry. J Bio-Environment Control 18 (1): 29-39

Ko IB (2015) Current Situation and Perspectives of Hydroponic System for Strawberry Cultivation in Korea. Dissertation, Konkuk University

Kwon HY, Kim JB, Lee HD, Ihm YB, Kyung KS, Park IH, Choi J (2004) Estimate of pesticide residues in tomato varieties using ratio of surface area to weight. The Korean J Pestic Sci 8(1): 30-37

Lee CR, Hong JH, Lim JS, Lee KS (2011) Residue Patterns of azoxystrobin and cyenopyrafen in grape between rainshield and plastic house conditions. The Korean J Pestic Sci 15: 97-103

Lee DY, Kim YJ, Park MH, Lee SH, Kim SG, Kang NJ, Kang KY (2013) Establishment of pre-harvest residue limit (PHRL) of fungicides azoxystrobin and difenoconazole on prunus mume fruits. The Korean J Pestic Sci 17(4): 307-313

Lee JW, Kim JY, Kim HG, Hur KJ, Kwon CH, Hur JH (2017) Residual characteristics of bistrifluron and chlorantraniliprole in strawberry (Fragaria ananassa Duch.) for establishing pre-harvest residue limit. The Korean J Environ Agric 32 (1): 57-62

Li H, Du H, Fang L, Dong Z, Guan S, Fan W, Chen Z (2016) Residues and dissipation kinetics of carbendazim and diethofencarb in tomato (Lycopersicon esculentum Mill.) and intake risk assessment. Regulatory Toxic \& Pharm 77: 200-205

MAFRA (2017) 2016 MARFA statistics. Ministry of Agficulture Food and 
Rural Affairs, http://www.lib.mafra.go.kr. Accessed Sep 2017

Mohapatra S, Lekha S (2016) Residue level and dissipation of carbendazim in/on pomegranate fruits and soil. Environ Monit Assess 188(7): 10

Nam MH, Jeon YN, Lee HC, Lee HD, Kang HK (2012) Comparative analysis between healthy and powdery mildew-infected plants of strawberry cultivar Seolhyang. Research in Plant Disease 18 (2): 80-85

NAQS (2017) 2016 Report on the status of residue of hazardous substances in agricultural products, National Agricultural Products Quality Management Service, Kimcheon

Park HI, Hwang JM, Kim BS, Lee MG, Choi YW, Lee MH, Jeong EJ, Kim
JH (2011) Residue of pesticides carbendazim and chlorpyrifos in different parts of red pepper. The Korean J Pestic Sci 15(3): 246-253

Park KH, Kim SH (2011) A comparative study of consumer preference for strawberries in korea and singapore. Korean J Agric Manag Policy 38: $321-340$

RDA (2016) Export agriculture. Rural Development Administration, RDA Web. http://www.nongsaro.go.kr. Accessed 12 Dec 2016

RDA (2017) Export agricultural products safe use technology. Rural Development Administration, Available from: http://www.nongsaro. go.kr. Accessed 12 Dec 2016 